\title{
Najstarsze dzieje parafii mielnickich
}

\author{
Antoni Mironowicz \\ Uniwersytet w Białymstoku, Polska \\ ORCID: 0000-0001-7856-2191 \\ amir@uwb.edu.pl
}

A. Mironowicz, The oldest history of Mielnik parishes, Elpis, 23 2021: 147-153.

\begin{abstract}
The oldest history of the Orthodox parishes in Mielnik shows that they were closely related to the history of the city. The first brick temple was built in the Ruthenian stronghold in the 13th century. The tradition of the thirteenth-century temple was related to the wooden church of the Nativity of the Blessed Virgin Mary built in 1431 at Drohicka Street, and then another one erected on the Ruthenian hill in 1614 and the present one built in the years 1821-1823. The Orthodox Church of the Resurrection of Christ situated on Brzeska Street at the beginning of the 16th century was of great importance to the inhabitants of the city. Rebuilt after a fire in 1648, it survived until 1878. In 1777, in the parish of the Nativity of the Blessed Virgin Mary, a cemetery chapel of the Protection of the Mother of God was built, which housed the revered icon of the Mother of God of the Protection.

Streszczenie: Najstarsze dzieje prawosławnych parafii mielnickich wskazują, że były one ściśle związane z dziejami miasta. Pierwsza murowana świątynia powstała w grodzie ruskim w XIII wieku. Do tradycji XIII - wiecznej świątyni nawiązywała wybudowana w 1431 roku drewniana cerkiew Narodzenia NMP przy ulicy Drohickiej na podzamczu a następnie kolejne wzniesione na wzgórzu ruskim w 1614 roku i obecna wybudowana w latach 1821-1823. Duże znaczenie dla mieszkańców miasta miała cerkiew Zmartwychwstania Chrystusa usytuowana przy ulicy Brzeskiej na początku XVI wieku. Odbudowana po pożarze w 1648 roku przetrwała do 1878 roku. Na terenie parafii Narodzenia NMP w 1777 roku wybudowano kaplicę cmentarną Opieki Matki Bożej, w której znajdowała się otoczona szacunkiem ikona Matki Boskiej Orantki.
\end{abstract}

Keywords: Orthodox Church, Mielnik, parish

Słowa kluczowe: Cerkiew prawosławna, Mielnik, parafia

Mielnik należał do jednych z najstarszych grodów na pograniczu polsko-ruskim. Gród ruski, założony prawdopodobnie przez księcia kijowskiego Jarosława Mądrego, położony był na prawym brzegu Bugu. Świadczą o tym wykopaliska archeologiczne prowadzone w minionym stuleciu na terenie Mielnika (Górska 1961; Rejniewicz 1987). W XI -XIII wieku istniały tu dwa, połączone ze sobą, systemy osad obronnych, które miały za cel ochronę i obsługę przeprawy na Bugu. Główne punkty osadniczo-obronne stanowiły dwa wzgórza na Górze Zamkowej i sąsiedniego ze znajdującym się na jej terenie cerkwią. System ten dopełniała osada po drugiej stronie Bugu (na Zabużu) i wyspa Ostrów (Michaluk 1993: 27). Nie ulega wątpliwości, że już w XI stuleciu funkcjonowała cerkiew grodowa przeznaczona do obsługi duszpasterskiej stacjonującej załogi i osadnictwa ruskiego. Cerkiew Bogurodzicy była wielokrotnie wzmiankowana w źródłach historycznych. Otwartym pytaniem, czy znajdowała się ona na wzgórzu grodowym, czy na terenie wybudowanego w pierwszej połowie XIV wieku zamku. Lokalizacja grodu ruskiego i zapisy źródłowe wskazują, że najstarsza świątynia mielnicka znajdowała się na wzgórzu, gdzie obecnie znajduje się cerkiew Narodzenia NMP.

Mielnik znajdował się w XI stuleciu w granicach diecezji turowsko-pińskiej, a następnie włodzimierskiej. Trudno jest odpowiedzieć na pytanie, kiedy nastąpiła zmiana przebiegu granicy pomiędzy biskupstwem turowskim a włodzimierskim? Zmiany spowodowane rozbiciem dzielnicowym i przesunięciami terytorialnymi księstw ruskich musiały wpłynąć na granice diecezji prawosławnych, sąsiadujących z ziemiami polskimi. Być może proces ten dokonał się pod wpływem nowych podziałów politycznych w 1135 roku, kiedy to książę turowski Izasław Mścisławicz opuścił swoją rezydencję i osiadł we Włodzimierzu Wołyńskim. Zmiany musiały być bardzo istotne, jeżeli w skład eparchii włodzimierskiej w połowie XII wieku weszły ziemie Wołynia na zachód od Słuczy i Horynia, Polesie z grodami Brześciem, Słonimiem, Grodnem, Wołkowyskiem i Kobryniem, tereny nad środkowym Bugiem z Mielnikiem, Drohiczynem i Bielskiem, Grody Czerwieńskie i Przemyśl oraz dorzecze górnego Dniestru z Haliczem. Diecezja włodzimierska obejmowała więc tereny od plemion litewskich na północy, poprzez pogranicze polskie i węgierskie na zachodzie, po tereny koczowników połowieckich na południu (Teodorovič, 1893: 26; Gil, 1999: 100; Pravoslavnâ̂ Enciklopediâ, 2000: 161). Obszar diecezji włodzimierskiej obejmował cały Wołyń, Polesie z grodami Brześciem, Słonimiem, Grodnem, Wołkowyskiem i Kobryniem, tereny nad Bugiem z Mielnikiem, Grody Czerwieńskie i Przemyskie oraz porzecze górnego Dniestru z Haliczem. W miarę powstawania nowych eparchii jej jurysdykcja kurczyła się i w końcu XIII wieku obejmowała zachodni i południowy Wołyń (powiaty włodzimierski i krzemieniecki) oraz południowe i środkowe Podlasie (ziemia brzeska, bielska i drohiczyńska) (Batûškov, 1888: 19; Teodorovič, 1893: 26; Jabłonowski, 1889: 103; Podskalsky, 2000: 281; Mironowicz, 2003: 82-85). 
W XIII wieku powstały kolejne biskupstwa prawosławne. Książę halicko-wołyński Daniel najpierw w 1223 roku erygował biskupstwo w Uhrowsku, a następnie w 1240 roku przeniósł je do Chełma (Batûškov, 1887: 14, 38, 39; Čistovič, 1882: 6; Gil, 1999: 61, 65-68). Władyctwo chełmskie zostało wydzielone z diecezji włodzimiersko-wołyńskiej. Początkowo granica wschodnia eparchii uhrowskiej opierała się na linii Bugu na północy i wschodzie. Zachodnia granica biskupstwa obejmowała kasztelanię lubelską i łukomską, należące do dzielnicy sandomierskiej. Do diecezji tej należały tereny ziemi chełmskiej i bełskiej. Rozwój terytorialny państwa Daniela Romanowicza na północy spowodował włączenie do diecezji chełmskiej południowego Podlasia z księstwem drohickim i ziemią mielnicką (Gil 1999: 101-111). Mielnik czasowo znalazł się w eparchii chełmskiej. Po przeniesieniu stolicy biskupstwa z Uhrowa do Chełma w niewielkim stopniu zmieniły się jego granice. Eparchia chełmska obejmowała nadal tereny na wschodzie do rzeki Bug, a dalej granica jej biegła wzdłuż Bugu do Niemirowa, Mielnika. Na północnym odcinku diecezja chełmska obejmowała obszar między Bugiem a Nurcem. Zachodnia granica biskupstwa sięgała do Liwca, dochodziła do zlewisk Tyśmienicy i Czarnej, do Wieprza w okolicy Kocka, dalej wzdłuż dolnego Wieprza do granicy katolickiej diecezji krakowskiej. W skład diecezji weszły nie tylko obszary podległe władzy księcia Daniela, ale też część dzielnicy sandomierskiej z zamieszkałą ludnością polską i ruską (Mironowicz, 2003: 95-98).

W 1264 roku zmarł Daniel Romanowicz, twórca potęgi Rusi Halickiej i założyciel eparchii chełmskiej. Śmierć najwybitniejszego z XIII-wiecznych książąt ruskich pogłębiła podziały między Haliczem a Włodzimierzem. Najstarszy z rodu Romanowiczów, książę włodzimierski Wasylko, zachował swoje ziemie, ale prowadził politykę zagraniczną nie zawsze zgodną z interesami książąt halickich. Dobra Daniela uległy podziałowi między jego synów. Szwarno otrzymał wschodnią część księstwa halickiego z Haliczem i całe Zabuże (Bełz, Czerwień, Chełm, Mielnik, Drohiczyn). Najmłodszy syn Lew dostał zachodnią część księstwa ze Lwowem i Przemyślem. Mścisław objął księstwo łuckie i trembowelskie. Czwarty syn Daniela, książę słonimski Roman w roku śmierci ojca już nie żył (Hrushevs'kyy, 1905: 92). Dzielnicę Szwarna objął książę Lew. Lew Daniłowicz przejął Chełm, Bełz, Czerwień, Halicz i Przemyśl. W jego imieniu północną częścią Zabuża, z Mielnikiem i Drohiczynem, zarządzał jego syn Jerzy. Ziemie Rusi Czarnej zostały zajęte przez księcia litewskiego Trojdena. W 1269 roku, po śmierci Wasylka, księstwo włodzimierskie przeszło we władanie jego syna Włodzimierza Wasylkowicza (1269-1289) (Mironowicz, 2011: 113-114).

Śmierć książąt Szwarny i Wasylka w 1269 roku zburzyła dotychczasową organizację terytorialną Cerkwi ruskiej. Fakt oddzielenia części spuścizny po Szwarnie księciu Jerzemu Lwowiczowi doprowadził do oderwania północnej części eparchii z Drohiczynem i Mielnikiem od Chełma. Ośrodek diecezjalny w Chełmie został połączony z Bełzem i Czerwieniem. W rezultacie tych zmian powstał nowy kształt granic diecezji chełmskiej i włodzimierskiej. Ponownie księstwa: drohickie, brzeskie, włodzimierskie znalazły się w granicach eparchii włodzimierskiej (Mironowicz, 2003: 103-104). Książęta ruscy, po opanowaniu ziem nad Bugiem do ujścia rzeki Nurzec wznieśli lub rozbudowali grody w Mielniku, Drohiczynie, Surażu, Brańsku i Bielsku. Ludność mazowiecka została całkowicie wyparta znad Muchawca i okolic Brześcia. Rozwój osadnictwa ruskiego został zahamowany dopiero w wyniku najazdów jaćwieskich (Wiśniewski, 1977: 9, 10).

Reasumując, pierwotnie cerkiew w Mielniku podlegała jurysdykcyjnie biskupom turowsko-pińskim, a następnie włodzimierskim (Jabłonowski, 1909: 227; Sosna, 1978: 64; Mironowicz, 2011: 64). Po krótkiej przynależności do eparchii chełmskiej w latach 1240-1269 większość ziemi podlaskiej z Mielnikiem weszła w skład Księstwa Halicko -Wołyńskiego i znalazło się pod zwierzchnictwem biskupów włodzimierskich. Taki stan rzeczy przetrwał do końca XVI wieku. Zależność od książąt ruskich południowych obszarów ziem podlaskich wywarła istotny wpływ na dzieje i charakter Cerkwi prawosławnej nad Bugiem i Narwią. Z okresu panowania książąt halicko-wołyńskich pochodzą najstarsze wzmianki o dziejach cerkwi mielnickiej. Latopis ipatiewski wspomina pod rokiem 1260 o murowanej grodowej cerkwi Narodzenia Najświętszej Marii Panny w Mielniku z cudowną ikoną „Spasa Izbawnika”. Według latopisu książę Daniel ulegając władzy chana tatarskiego Burunaja, wysłał ks. Wasylka na podbój Litwy. „Jechał Wasilko za brata i prowodi jego do Berestia, i posła snim swoja ludi, i pomolisia Bogu swiatomu Spasu Izbawniku, jaże jest ikona w gorodie Mielnicy w cerkwi św. Bogorodzicy, nynie stoit w wielice czesti i obieszczasia Daniło korol ukrasiti ju" (Bobrovskij, 1863: 978; Polnoe sobranie russkih letopisej, 1843: 846-847; Golubinskij, 1904: 306; Pańko, 1962: 15; Mironowicz, 2007: 168-174). Siedem lat wcześniej książę halicki Daniel koronował się w cerkwi Narodzenia NMP w Drohiczynie (Mironowicz, 2003: 47-52). Jego śmierć w 1264 roku spowodowała osłabienie Księstwa Halicko-Wołyńskiego i wzrost potęgi Litwy, która za rządów Giedymina (1315-1341) i Olgierda (13441377) wchłonęła ziemię podlaską. W granicach Wielkiego Księstwa litewskiego ostatecznie ukształtowana została struktura organizacyjna Kościoła prawosławnego, ale nie zmieniła się przynależność diecezjalna cerkwi mielnickiej.

Rozwój gospodarczy Wielkiego Księstwa Litewskiego w II połowie XV wieku nie ominął znajdującej się w jego granicach ziemi podlaskiej. Zagospodarowanie jej przez książąt litewsko-ruskich pociągnęło rozwój osadnictwa ruskiego nad Krzną, Bugiem, Narwią i Biebrzą. Osadnictwo ruskie zdominowało obszar południowego Podlasia, a na północ od rzeki Bug zwartym obszarem sięgało okolic Brańska i Suraża. Szczególnie ludna była kolonizacja ruska koło Brańska, sięgająca aż po rzekę Mień. Zbudowano na tym terenie najdalej wysuniętą na zachód cerkiew wiejską w Hodyszewie. Najdalszymi na zachód wyspami ruskimi z cerkwiami były miasta prywatne Ciechanowiec 
i Wysokie (Mazowieckie). To ostatnie, ze wsiami ruskimi Osipy, Bożegi i Bryki, podlegało namiestnikowi z Drohiczyna (Wiśniewski, 1977: 17). Liczne były fundacje cerkwi przez książąt litewsko-ruskich w starych miastach jak Suraż, Bielsk, Drohiczyn i Mielnik. W Mielniku Olechno Kmita Sudymontowicz i jego żona Elżbieta ufundowali w 1431 roku cerkiew Narodzenia NMP (Vestnik Zapadnoj Rossii, 1869: 83). Wiele faktów wskazuje, że cerkiew została ufundowana na podzamczu przy ulicy Drohickiej, a nie na dawnym ruskim wzgórzu grodowym. Cerkiew była ufundowana $\mathrm{w}$ czasie budowy przez książąt litewskich (wielkiego księcia Witolda) zamku z kościołem św. Mikołaja. Mielnik był narażony na najazdy od zachodu i północy, co spowodowało konieczność budowy sprawnego systemu obronnego. Powstał on w I połowie XIV wieku opierając się zapewne na istniejącej strukturze grodowej. Zamek Mielnik wraz z Bielskiem podlegał zamkowi w Drohiczynie, a cały obszar namiestnikowi w Grodnie. Zamek strzegł szlaków komunikacyjnych: Drohiczyn Mielnik - Brześć - Grodno, Mielnik - Bielsk, sprawował kontrolę nad przeprawą.

W tym samym czasie ufundowana została parafia prawosławna w Siemiatyczach przez właściciela grodu tegoż Sudymontowicza wraz z żoną Fedorą (Sosna, 1989: 51-55; Mironowicz, 2017: 42-49). Dokument fundacyjny Olechny Kmity Sudymontowicza, właściciela Siemiatycz, z 1431 roku, uważany był przez wielu badaczy za falsyfikat. Według Józefa Maroszka został on sfałszowany w XVII lub XVIII wieku, ażeby przekonać dziedziczkę Siemiatycz Annę Jabłonowską do legalności dochodów miejscowego duchownego (Maroszek, 1989: 10-12; Korczak, 1998: 99; Boniecki, 1887: 25-26). Nawet jeżeli dokument nie jest autentyczny, to opierał się na osnowie historycznej. Wiarygodne zostały podane w nim fakty i osoby. Olechno Kmita Sudymontowicz był podczaszym hospodarskim (14481477), podkomorzym trockim (1449-1453), namiestnikiem grodzieńskim (1458-1459) i połockim (1463-1476), wojewodą wileńskim i kanclerzem Wielkiego Księstwa Litewskiego (1477-1490/1491). Kazimierz Jagiellończyk nadal mu liczne dobra w tym i dobra siemiatyckie (Polski Słownik Biograficzny, 2007-2008: 351-353; Niesiecki, 1841, s. 560).

Dokument erekcyjny dla cerkwi siemiatyckiej miał wystawić 25 kwietnia 1431 roku Olechno Kmita Sudymontowicz. Problem jest tylko w tym, że Olechno nie miał żony Fedki, a imię takie miała małżonka jego brata Aleksego. Olechno miał żonę o imieniu Elżbieta. Sudymont, książę litewski miał dwóch synów Aleksego i Olechnę (Aleksandra). Wynika $\mathrm{z}$ tego, że w tym samym roku Aleksy wraz z żoną Fedorą był fundatorem cerkwi siemiatyckiej (AVAK, 1867: 1-2; Sosna, 2006: 363) a Olechno z żoną Elżbietą był fundatorem cerkwi w Mielniku.

Dokument z 1431 roku zawierał autentyczne informacje o uposażeniu duchownego, które składało się z 3 włók ziemi położonej w trzech polach siemiatyckich, 3 włóki ziemi w Boratyńcu Ruskim, 4 włóki sianożęci w Słochach, czterech poddanych w Boratyńcu Ruskim z obowiązkiem odbywania jednego dnia w tygodniu pańszczyzny, dzie- sięcina z ponad 20 włók we wsi Klekotowie i Słochach. Dodatkowo po kopie żyta z każdej włóki, dziesięcina z ponad 6 włók w Boratyńcu Ruskim oraz ze wsi Pirogowicze, Wołychowicze (dziś Wakułowicze), Resetniki i Kajanka po snopów 15, wolność mlewa w młynach dziedziców siemiatyckich na rzekach Moszczonej i Kajanka, jezioro obok Bugu koło wsi Turna i Wólka oraz drwa z lasów majątkowych na opał i inną potrzebę (Sosna, 2006: 364-365).

Nie ulega wątpliwości, że cerkiew siemiatycka istniała w 1456 roku, kiedy syn Olechny, Michał Kmita Sudymontowicz, wyremontował zbudowaną przez jego wuja świątynię, a proboszcza uposażył dodatkowo $\mathrm{w}$ grunta orne i łąki we wsi Myszkowo i w uroczysku Gryczówka. Michał Kmita Sudymontowicz ufundował też w 1456 roku pierwszy drewniany kościół parafialny pw. św. Michała. Michał Kmita Sudymontowicz z Chożowa zmarł około 1469 roku. W nieznanych bliżej okolicznościach dobra siemiatyckie około 1470 roku przeszły w ręce Olechny Kmity Sudymontowicza brata Aleksego. Córka Olechny Aleksandra wyszła za mąż w 1484 roku za wojewodę ruskiego Mikołaja Tęczyńskiego z Tęczyna h. Topór zwanego Krakowczykiem (zm. 26 października 1497 roku), miecznika krakowskiego (1483-1485) i wojewody bełskiego (14941496) i wniosła mu te dobra w posagu (Dworzaczek, 1959: tab. 94).

Cerkiew Narodzenia NMP w Mielniku została ufundowana w 1431 roku na nowym miejscu. Inwentarz zamku mielnickiego z 1551 roku opisywał, że „na trzynastym placu, licząc od Rynku stała cerkiew pw. Narodzenia Najświętszej Marii Panny" (AGAD ASK: k. 12v'. Przeprowadzający pomiarę włóczną w 1560 roku Dymitr Sapieha nie znał okoliczności jej fundacji. Zapisał jedynie, że świątynia ,uposażona została we dwie włóki, wolne od opłat”, zaś w 1560 roku jej grunta uprawne, położone w Mielniku, obejmowały 3 włóki, 12 morgów i 41 prętów (Michaluk, 1999: 25; Sosna, 2004: 228). W tym czasie proboszczem parafii Narodzenia NMP w Mielniku był ojciec Dawid. Cerkiew Narodzenia NMP była drewniana i postała na długo przed 1551 rokiem, kiedy spłonął zamek wraz z całą kancelarią (Sbornik statej, 1887: 107). Z pożaru ocalały obiekty murowane: kościół św. Mikołaja i wieża wjazdowa (AGAD ASK: k. 151v). Pożar zamku nie zniszczył cerkwi Narodzenia NMP znajdującej się na podzamczu. W 1576 roku przy cerkwi Narodzenia NMP było dwóch duchownych posiadających trzy włóki gruntów wolnych od podatku (AGAD ASK: k. 12v; Mironowicz, 1991: 84).

Stolica Ziemi Mielnickiej należała w XVI wieku do dobrze rozwiniętych gospodarczo ośrodków podlaskich. Mielnik był ważnym centrum polityczno-administracyjnym na Podlasiu. W nim odbywały się sejmiki ziemskie i sprawy sądowe dotyczące całej Ziemi Mielnickiej. Położenie miasta nad Bugiem sprzyjało rozwojowi handlu i rzemiosła. Rejestr poborowy z 1580 roku wymienia 62 rzemieślników. Najliczniejszą grupę wśród nich stanowili przedstawiciele rzemiosł spożywczych (AGAD ASK: k. 231-232v.; Alexandrowicz, 1964: 151). 
Cerkiew Narodzenia NMP funkcjonowała na podzamczu do 14 lutego 1614 roku, kiedy została zniszczona podczas pożaru (AVAK, 1908: 197-198). Dzięki zabiegom proboszcza parafii ks. Hieronima i wsparciu finansowemu cechów świątynia szybko została odbudowana na miejscu, gdzie niegdyś znajdowała się na sąsiadującym z zamkiem wzgórzu murowana cerkiew Bogurodzicy. Prawdopodobnie tam znajdowała się pierwotna lokalizacja grodu ruskiego. Odbudowie sprzyjała sytuacja w Radzie Miejskiej, zdominowanej przez Rusinów. Tolerancyjne stanowisko starostów mielnickich umożliwiało oblatowanie i wpisywanie do ksiąg grodzkich dokumentów istotnych w swej treści dla podlaskich cerkwi i monasterów prawosławnych. Silną pozycję materialną posiadało prawosławne duchowieństwo mielnickie (AVAK, 1908: 184-185, 239). Było ono inspiratorem, a może nawet i wykonawcą, kopiowania ksiąg liturgicznych na potrzeby sąsiednich parafii (Opisanie Rukopisnogo otdeleniâ Vilenskoj publičnoj biblioteki biblioteki 1895: 37).

Do takiej lokalizacji odbudowanej świątyni odnosi się zapis z wizytacji cerkwi z 1726 roku. W tym czasie drewniana cerkiew Narodzenia NMP stała na „ostrej górze, na placu dawnym, gdzie cerkiew murowana była" (APL CHKG-K: k. 139v-140). Określenie: ,cerkiew murowana” odnosi się do świątyni grodowej, zapewne o charakterze obronnym. Warto zaznaczyć, że na podzamczu gdzie stała cerkiew z 1431 roku wybudowano na początku XVII wieku $\mathrm{w}$ oparciu o materiał $\mathrm{z}$ budynku sądowego murowany kościół Trójcy Świętej. W 1871 roku kościół został zamieniony na cerkiew Świętego Ducha. W maju 1918 roku cerkiew spłonęła, a należące do niej grunta zostały rewindykowane przez władze państwowe. Ruiny cerkwi Św. Ducha zachowały się do dnia dzisiejszego (Sosna, 2000: 320).

W latach siedemdziesiątych XVIII wieku na zachodniej części zamczyska wzniesiono kaplicę pw. Matki Boskiej Opieki (Sosna, 2000: 320). Kaplica została wzniesiona w 1777 roku. W tym to bowiem roku została wyłowiona z rzeki ikona Matki Bożej Opieki (Pokrowska), którą ks. Jakub Bielawski początkowo umieścił w cerkwi Narodzenia NMP, a następnie dla tej ikony proboszcz wybudował na starym „,erkwisku” kaplicę Matki Bożej Opieki. Przy tej kaplicy, od 1782 roku zaczęto grzebać zmarłe osoby, dając początek obecnemu cmentarzowi (Nesteruk, 1980: 31-35). Kaplicę wybudowano na zachodniej części zamczyska przyległego do Góry Zamkowej.

Drugą świątynią prawosławną była cerkiew Zmartwychwstania Chrystusa. Cerkiew była usytułowana przy ulicy „Woskriesienskiej”, która wychodziła z południowo -zachodniej części Rynku i przecinała ulicę Brzeską. Jej XVI-wieczna nazwa pochodzi od wezwania cerkwi Zmartwychwstania Pańskiego, stojącej na ostatniej parceli po prawej stronie ulicy. W 1560 roku plac po lewej stronie ulicy, a naprzeciwko cerkwi, należał do duchownego tej cerkwi, Dziemieniczego (AGAD ASK: k. 12v; Michaluk, 1993: 34). Pierwsza wzmianka o świątyni Zmartwychwsta- nia Chrystusa pochodzi z 1551 roku wraz z informacją o znajdującym się w jej pobliżu kościele Narodzenia NMP (AGAD ASK: k. 12v'. Cerkiew ta prawdopodobnie została ufundowana na początku XVI wieku, kiedy Mielnik uzyskał od Aleksandra Jagiellończyka prawa miejskie magdeburskie (27 października 1501 r.) (Akty Litovsko-Russkogo gosudarstva 1899: 99-100). O wcześniejszej proweniencji świątyni świadczy jej usytuowanie w okresie nowego rozplanowania rynku i parceli miejskich.

Na początku XVII wieku Mielnik stał się ważnym ośrodkiem Kościoła prawosławnego na Podlasiu. Na jego terenie funkcjonowały dwie parafie prawosławne: Zmartwychwstania Chrystusa i Narodzenia NMP (AGAD ASK: k. 12v). Duchowieństwo i wierni obu parafii odrzucili postanowienia synodu brzeskiego i pozostali $\mathrm{w}$,wierze greckiej”. Ówczesny pleban katolicki Jan Witkowski, wykorzystując delegalizację Kościoła prawosławnego zażądał dziesięciny od mieszczan prawosławnych. Burmistrz miasta, Łukasz Markowicz, w imieniu zdominowanej przez prawosławnych Rady Miejskiej 13 kwietnia 1600 roku, odmówił oddawania łacińskiemu duchownemu dziesięciny, gdyż „tej nigdy jako przodkowie naszy ani my sami nie oddawali i teraz dawać nie powinni” (AVAK, 1908: 150). Proboszcz katolicki odwołał się do króla Zygmunta III, który polecił podkomorzemu drohickiemu Hieronimowi Irzykowskiemu rozstrzygnąć spór. Podkomorzy, nie wnikając w sytuację prawną, 15 czerwca 1600 roku przyznał dziesięcine - 73 włók miejskich - księdzu Janowi Witkowskiemu (AVAK, 1908: 153-156). Decyzja Hieronima Irzykowskiego wywołała protesty mieszczan mielnickich. W ich imieniu burmistrz, Łukasz Markowicz, 23 czerwca złożył w urzędzie grodzkim oświadczenie, w którym dowodził, że „włók w mieście Mielniku siedemdziesiąt trzy, które nie katoliki, ale Rusini dzierżą i z nich powinności, a dochody do cerkwi ruskich $\mathrm{z}$ dawnych czasów od przodków swych oddawają". Burmistrz ponadto dodał, że „W mieście Mielniku włók tylko dwadzieścia półdziewięty, z których katoliki a mieszczanie dziesięciny do kościoła oddawali, co na każdym miesiącu mieszczanie mielnicy gotowi się ukazać" (AVAK, 1908: 156). Duchowny łaciński nie przyjął thumaczeń burmistrza i 5 lipca 1600 roku przed urzędem grodzkim domagał się egzekucji postanowień podkomorzego drohickiego. W odpowiedzi burmistrz Łukasz Markowicz oznajmił, że ,wedle króla Jego Mości regestrów y ksiąg miejskich pokazali, to jest dwudziestu i półdziewiętu włók, $\mathrm{z}$ tech powinni będziemy dawać y dać chcemy zarówno z pany katoliki, ale z tech, które Jego Mość pan inquisitor króla Jego Mości onemu nad regestra i księgi pokazane przywłaszczać raczył z tego nie damy, ale po naukę do Jego Królewskiej Mości posyłamy" (AVAK, 1908: 156-157). Wyjaśnienia te nie przyniosły rezultatu. Protestujący duchowny łaciński wymusił na woźnym ziemi mielnickiej, Mateuszu Sikorskim, 28 sierpnia wezwanie na sąd wszystkich mieszczan, którzy nie oddawali dziesięciny (AVAK, 1908: 157-161). Mimo, iż ostatecznie do rozprawy sądowej nie doszło, to spór o dziesię- 
cinę powracał w następnych latach i wpłynął negatywnie na stosunki wyznaniowe w mieście.

Zaostrzenie się konfliktów wyznaniowych nastąpiło w latach 1607-1611. Metropolita unicki Hipacy Pociej podjął próbę administracyjnego podporządkowania swej jurysdykcji parafii mielnickich. Duchowieństwo i wierni wyznania prawosławnego wraz z protopopem brzeskim Piotrem Janowiczem 23 sierpnia 1607 roku złożyli w urzędzie grodzkim protest przeciw narzuceniu im unii i uwięzieniu proboszcza cerkwi Narodzenia NMP Konstantyna. Protestujący zwracali uwagę na naruszenie przez duchowieństwo łacińskie uchwalonej w tym roku na sejmie warszawskim konstytucji „Religia Grecka”, która gwarantowała prawa i wolność odprawiania nabożeństw ludności prawosławnej. Protest podpisali przedstawiciele duchowieństwa i wiernych innych parafii. Pod dokumentem znalazły się podpisy starszych cechu należących do parafii Zmartwychwstania Chrystusa w Mielniku: „za uchwałoju i pozwolenijem wsiej parafii cechu Woskresienia Chrystowa Grigore Omelianowacz, rajca, własnoju rukoju. Na miestu starosty togo cechu Bogdana Wasilewicza, iż pisaci nie umieł Wasil Siergiejewicz, własnuju rukoju”. (AVAK, 1908: 169-171)

Dodatkową przyczyną podziału wśród mieszczan Mielnika były zmiany w kalendarzu świąt kościelnych. Podział ten dokonywał się nie zawsze według kryterium wyznaniowego. Przykładem są tu oświadczenia Andrzeja Wierzbińskiego (prawosławnego) z 25 grudnia 1607 roku przed urzędem grodzkim o obchodzeniu święta Bożego Narodzenia według kalendarza gregoriańskiego i Mikołaja Dawidowskiego (katolika) z 25 grudnia 1608 roku o obchodzeniu tego święta według kalendarza juliańskiego (AVAK, 1908: 172-173, 192-193). Z dezaprobatą duchowieństwo łacińskie przyjmowało miejscową tradycję i obrzędy. Ksiądz Jan Witkowski oskarżył 1 czerwca 1610 roku przed urzędem starościńskim wójta Jana Szczerbicza i wszystkich mieszkańców miasta o udział w zabawach związanych ze świętem „Klęczenie”, tj. Zielone Świątki. Duchowny katolicki zarzucił Rusinom kultywowanie zwyczajów pogańskich (AVAK, 1908: 185186). Starosta nie miał podstaw do wyciągnięcia $\mathrm{w}$ stosunku do nich jakichkolwiek konsekwencji. W tej sytuacji pleban mielnicki ponownie zażądał od prawosławnych dziesięciny. Woźny mielnicki, Adam Szmurło, polecił jej dostarczenie. Decyzja woźnego spowodowała długotrwale spory w urzędzie grodzkim (AVAK, 1908: 191-192). Dodatkowym problemem dla wiernych Kościoła prawosławnego stała się odbudowa cerkwi Narodzenia NMP, spalonej 14 lutego 1614 roku (AVAK, 1908: 197-198). Dzięki zabiegom proboszcza parafii Hieronima i wsparciu finansowemu cechów inwestycja szybko została ukończona.

Konflikty wyznaniowe z lat 1633-1636 nie ominęły Mielnika. Przebiegały one jednak w łagodniejszej formie i dotyczyły głównie sporu o dziesięcinę między katolickim plebanem a mieszczanami obu parafii prawosławnych. Jeszcze w 1644 roku duchowni cerkwi Zmartwychwstania Chrystusa i Narodzenia NMP pozostawali w ,wierze greckiej" (AGAD ASK: k. 557). W potwierdzeniu królewskim uposażenia cerkwi mielnickich dwa lata później występują już jako prezbiterzy uniccy. Zapewne spór o dziesięcinę i brak bractw cerkiewnych spowodował zmianę oblicza wyznaniowego kleru mielnickiego. Przejście na unię nie zahamowało roszczeń plebanów katolickich do dziesięciny i jurysdykcji nad wiernymi. W tej sytuacji duchowni Nikifor Wierzba i Stefan Jaroszewicz 20 października 1646 roku uzyskali od króla Władysława IV potwierdzenie uposażenia swych parafii. Monarcha potwierdził dla nich ,W miasteczku naszym Mielniku w uniej będących z włók trzydziestu mieszczan tamecznych po kopie jednej żyta ozimego, a drugiej kopie jarzyny z każdej włóki na każdy rok, tak i ze wsiów Borszuka, Szcepielec, Horoszkowey Woli i Klepaczowa do cerkwie Zmartwychwstania Pańskiego, ze wsiów zaś drugich Hołowszyc, Mierzwia, Mosczoni y Radziłówky do cerkwie Narodzenia Najświętszej Panny Mariej dziesięcina z dawna należała (...)" (AVAK, 1908: 358-359). Mimo przywileju królewskiego następny pleban łaciński, Jan Baptysta wymógł na Janie Kazimierzu wezwanie 23 czerwca 1649 roku na sąd mieszczan, którzy zalegali z dziesięciną. Wezwanie objęło osoby należące do parafii unickich. Rozstrzygający spór starosta mielnicki, Wojciech Mleczko, wobec braku podstaw prawnych dla żądań księdza Jana Baptysty, zawiesił 3 sierpnia oddawanie mu dziesięciny ze spornych włók miejskich (AVAK, 1908: 370-372).

Spór o dziesięcinę zbiegł się z odbudową cerkwi Zmartwychwstania Chrystusa, spalonej w 1648 roku. W przedsięwzięciu tym uczestniczyli mieszczanie i szlachta. Np. ziemianin królewski z województwa brzeskiego Jerzy Mickiewicz oddał na budowę cerkwi drewno ze spichlerza nad Bugiem (AVAK, 1908: 362-363). Zaangażowanie się osób spoza Mielnika pozwoliło na dokończenie prac budowlanych, albowiem po potopie szwedzkim znacznemu zmniejszeniu uległa liczba parafian. W 1662 roku parafia Zmartwychwstania Chrystusa liczyła 62 rodziny (AVAK, 1908: 526-527). Nie uległo zmianie uposażenie mielnickiego duchowieństwa (AGAD, Zbiory Czartoryskie: k. 681; APB: k. 53v, 58v.). Wizytacje cerkwi mielnickich z 1726 roku potwierdzają posiadanie dziesięciny w wielkości określonej w potwierdzeniu Władysława IV. Źródło to wskazuje na pierwotny prawosławny charakter obu parafii mielnickich (APL CHKG-K: k. 338v-340) i przetrwanie w XVIII wieku tradycji o cerkwi Bogurodzicy z kultem ikony Spasa Izbawnika. W opisie parafii Narodzenia NMP wyszczególniono jej usytuowanie ,plac dawny, gdzie cerkiew murowana była" (Polnoe sobranie russkih letopisej, 1843: 846-847). Taki zapis wskazuje na inne miejsce jej lokalizacji aniżeli drewnianej cerkwi Narodzenia NMP stojącej w XVI wieku po prawej stronie ulicy Drohickiej (APL CHKG-K: k. 780). Warto przypomnieć, że cerkiew z 1614 roku stanęła więc na miejscu najstarszej murowanej obronnej świątyni mielnickiej Bogurodzicy znajdującej się w XIII stuleciu przy grodzie ruskim. Wizytacja parafii Narodzenia NMP i Zmartwychwstania Chrystusa z 1775 roku nie wykazała większych zmian w wielkości ich uposażenia i liczbie wiernych (APL CHKG-K: k. 590-591). Do parafii Narodzenia NMP należały wierni z Mielnika, 
Osłowa, Młyna, Stankowicz, Maćkowicz, Kudelicz, Homoty, Pawłowicz, Oksiutycz, Moszczonej, Mierzwic, Hołowczyc i Radziwiłłówki. Obecna świątynia została zbudowana w latach 1821-1823 niedaleko drewnianej na wzgórzu w sąsiedztwie cmentarza. Cerkiew Narodzenia NMP w 1875 roku została przebudowana i wzbogacona o pięć kopuł. Kilkakrotnie remontowana przetrwała do dnia dzisiejszego (Sosna, 2000: 322).

Do naszych czasów nie zachowała się natomiast cerkiew Zmartwychwstania Chrystusa. Wizytacja z 1726 roku opisuje cerkiew Zmartwychwstania Chrystusa jako „drewnianą, jeszcze nie starą (...) na górze niczym nie grodzona”. I dalej „,dach na niej z tarcic, bez kopuły i bez krzyża, dzwonnica nowa i jeszcze nie pokryta (...). W babińcu nie ma posadzki. Drzwi do cerkwi na trzech zawiasach z zaszczepką łańcuchową i zamkiem wiszącym, fontanna kamienna z wodą święconą" (APL CHKG-K: k. 780). Parafia Zmartwychwstania Chrystusa obejmowała wschodnią część miasta oraz wsie prawobrzeżne: Mętną, Sutno, Wajków i Adamowo. Według wizytacji z 1774 roku cerkiew wymagała remontu, brakowało w niej podłogi i ogrodzenia. Nie było domu parafialnego w wyniku czego nie posiadała własnego duchownego. Decyzją władz cerkiewnych w 1836 roku parafia Zmartwychwstania Chrystusa została zlikwidowana a jej wiernych ze wsi Mętna, Sutno, Wojków i Adamowo przyłączono do parafii Narodzenia NMP w Mielniku (Mironowicz 1991: 260). W 1878 roku materiał pozyskany z rozbiórki cerkwi został przekazany na remont cerkwi Przemieniania Pańskiego na św. Górze Grabarce (Sosna, 2000: 319).

Najstarsze dzieje prawosławnych parafii mielnickich wskazują, że były one ściśle związane z dziejami miasta. Pierwsza murowana świątynia powstała $\mathrm{w}$ grodzie ruskim w XIII wieku. Cerkiew była znana z przechowywania cudownej ikony Chrystusa Zbawiciela, którego kult rozwinął się wzdłuż rzeki Bug. Do tradycji XIII - wiecznej świątyni nawiązywała wybudowana w 1431 roku drewniana cerkiew Narodzenia NMP przy ulicy Drohickiej na podzamczu, a następnie kolejne wzniesione na wzgórzu ruskim w 1614 roku i obecna wybudowana w latach 1821-1823. Duże znaczenie dla członków mieszkańców miasta miała też cerkiew Zmartwychwstania Chrystusa usytuowana przy ulicy Brzeskiej na początku XVI wieku. Świątynia przez wiele dziesiątków lat skupiała mieszkańców Mielnika i okolic. Odbudowana po pożarze w 1648 roku przetrwała do 1878 roku. Na terenie parafii Narodzenia NMP w 1777 roku wybudowano kaplicę cmentarną Opieki Matki Bożej, w której znajdowała się otoczona szczególną czcią ikona Matki Boskiej Orantki (Nesteruk 1980: 31-40). O jurysdykcję nad nią i wiernymi bezskutecznie zabiegali w XVIII wieku duchowni katoliccy (Opisaniâ dokumentov arhiva zapadnorusskih uniatskih mitropolitov, 1897: 214). Obecnie kaplica i ikona Matki Boskiej Orantki stanowi jeden z najstarszych obiektów prawosławnego dziedzictwa w mieście.

\section{Wykaz skrótów}

AGAD, ASK - Archiwum Główne Akt Dawnych w Warszawie, Archiwum Skarbu Koronnego

APB - Archiwum Państwowe w Białystoku

APL, CHKG-K - Archiwum Państwowe w Lublinie, Chełmski Konsystorz Grecko-Katolicki

AVAK - Akty, izdavayemyye Vilenskoyu komissiyeyu dlya razbora drevnikh aktov, t. XXXIII, Akty, otnosyashchiyesya $k$ istorii Zapadno-russkoy tserkvi, Vil'na 1908

\section{Bibliografia}

\section{Źródła}

Archiwum Główne Akt Dawnych w Warszawie, Archiwum Skarbu Koronnego, dz. 56, M2, k. 12v.

Archiwum Główne Akt Dawnych w Warszawie, Zbiory Czartoryskie, rkps. 1099, k. 681.

Archiwum Państwowe w Białystoku, Akta miasta Mielnika, nr 1, k. $53 \mathrm{v}, 58 \mathrm{v}$.

Archiwum Państwowe w Lublinie, Chełmski Konsystorz Grecko-Katolicki, nr 817, k. 139v-140.

Akty izdavaemye Vilenskô̂ Arheografičeskô̂ Komissieû, vysočajše učreždennô̂ dlâ razbora drevnih aktov v Vil'ne. (1867). (t. II, s. 1-2). Vil'no.

Akty, izdavaemye Vilenskô̂ komissiê̂ dlâ razboradrevnih aktov. (1908). t. XXXIII. Akty, otnosâsiesâ k istorii Zapadno -russkoj cerkvi (s.150, 197-198). Vil'no.

Akty Litovsko-Russkogo gosudarstva. (1899). t. I. (1390-1529). (194, s. 99-100). M. Dovnár-Zapól'skij (red.). Moskva.

Opisaniâ dokumentov arhiva zapadnorusskih uniatskih mitropolitov. (1897). t. II. (1700-1839 gg.). (1812, s. 214). Sankt-Peterburg.
Opisanie Rukopisnogo otdeleniâ Vilenskoj publičnoj biblioteki. (1895). (Vyp. 1. nr 97, s. 37), Vil'na,

Polnoe sobranie russkih letopisej. (1843). (t. II, s. 846-847). Sankt-Peterburg.

\section{Literatura}

Alexandrowicz, S. (1964). Powstanie i rozwój miast województwa podlaskiego (XV - I poł. XVII w.). Acta Baltico-Slavica (t. I., s. 151).

Boniecki, A. (1887). Poczet rodów w Wielkim Księstwie Litewskim w XV i XVI wieku. Warszawa.

Dworzaczek, W. (1959). Genealogia. Warszawa.

Gil, A. (1999). Prawostawna eparchia chetmska do $1596 r$. Lublin.

Górska, I. (1961). Dokumentacja prac ratowniczych przeprowadzonych $w$ latach 1959-1961, Archiwum Konserwatora Zabytków Archeologicznych w Białymstoku, maszynopis.

Jabłonowski, A. (1909). Podlasie (t. IV, cz. II.). Źródła dziejowe (t. XVII, cz. II, s. 227). Warszawa. 
Jabłonowski, A. (1889). Ziemie ruskie, Wołyń i Podole. Warszawa.

Korczak, L. (1998). Litewska Rada wielkoksiążęca w XV wieku. Kraków.

Maroszek, J. (1989). Siemiatycze jako ośrodek dóbr ziemskich w XV-XVII w. (do 1801 r.). W: H. Majecki (red.), Studia i materiały do dziejów Siemiatycz (s. 10-12). Warszawa.

Michaluk, D. (1993). Rozwój układu przestrzennego Mielnika w XIII-XVIII wieku. Studia Podlaskie (t. IV, s. 27). Białystok.

Michaluk, D. (1999). Mielnik. Stolica Ziemi Mielnickiej na Podlasiu (do końca XVIII wieku). Mielnik.

Mironowicz, A. (2011). Biskupstwo turowsko-pińskie w XI-XVI wieku. Białystok.

Mironowicz, A. (2017). Dzieje parafii prawosławnej świętych apostołów Piotra i Pawła w Siemiatyczach. Cerkiewny Wiestnik (R. LXIV, nr 4, s. 42). Warszawa.

Mironowicz, A. (2003). Kościót prawosławny w państwie Piastów i Jagiellonów. Białystok.

Mironowicz, A. (1991). Podlaskie ośrodki i organizacje prawostawne w XVI i XVII wieku. Białystok.

Mironowicz, A. (2007). Sanktuarium prawosławne na Św. Górze Grabarce. Białoruskie Zeszyty Historyczne (nr 27, s. 168). Białystok.

Mironowicz, A. (2003). 750 rocznica koronacji księcia halickiego Daniela. Cerkiewny Wiestnik (nr 2, s. 47). Warszawa.

Nesteruk, E. (1980). W imię prawdy. Wiadomości PAKP (z. 1-4, s. 31).

Niesiecki, K. (1841). Herbarz Polski (t. VIII, s. 560). Lipsk.

Pańko, E. (1962). Historia Prawosławnej Cerkwi w Siemiatyczach. Cerkownyj Wiestnik (nr 3, s. 15).

Podskalsky, G. (2000). Chrześcijaństwo i literatura teologiczna na Rusi Kijowskiej (988-1237). Kraków.

Polski Słownik Biograficzny. (2007-2008). (t. 45, s. 351). Kraków.

Rejniewicz, Ł. (1987). Dokumentacja badań archeologicznych przeprowadzonych w latach 1985-1987, Archiwum Konser- watora Zabytków Archeologicznych w Białymstoku, opracowania maszynopis.

Sosna, G. (2004). Cerkiewna własność ziemska na Białostocczyźnie $w X V$-XX wieku. Zbiór materiałów. Białystok.

Sosna, G. (1978). Historyczny zarys Kościoła prawosławnego od zarania dziejów do chwili obecnej na terenie województwa białostockiego. Wiadomości Polskiego Autokefalicznego Kościoła prawosławnego. (z. 3-4, s. 64).

Sosna, G. (2000). Katalog świątyń i duchowieństwa prawosławnej diecezji warszawsko-bielskiej. Elpis (nr 3, s. 320).

Sosna, G. (1989). Rys historii parafii prawosławnej w Siemiatyczach. W: H. Majecki (red.), Studia i materiaty do dziejów Siemiatycz (s. 51). Warszawa.

Sosna, G. (2006). Święte miejsca i cudowne ikony. Prawostawne sanktuaria na Białostocczyźnie. Białystok.

Wiśniewski, J. (1977). Osadnictwo wschodniej Białostocczyzny. Acta Baltico-Slavica (t. XI). Wrocław.

Batûškov, P. N. (1888). Volyn', istoričeskiâ Sud'byûgo-Zapadnago kraâ. Sankt-Peterburg.

Batûškov, P. N. (1887). Holmskaâ Rus', istoričeskie sud'by russkogo Zabuž'â. Sankt-Peterburg.

Bobrovskij, P. O. (1863). Materialy dlâ geografii i statistiki Rossii, sobrannye oficerami General'nogo štaba. Grodnenskâ̂ guberniâ č. II. Priloženiâ. Sankt-Peterburg.

Vestnik Zapadnoj Rossii. Istoriko-literaturnyj žurnal. (1869). g. VII, kn. 7, t. III, otd. 2. Vil'no.

Golubinskij, E. (1904). Istoriâ russkoj cerkvi (t. I, č. 1.). Moskva.

Gruševs'kij, M. (1905). İstorîa Ukraïni-Rusi (t. III). L'vìv.

Pravoslavnaâ Enciklopediâ. Russkaâ Pravoslavnaâ Cerkov'. (2000). (s. 161, karta I., II.). Moskva.

Sbornik statej, raz"âsnâûsih pol'skoe delo po otnošeniû k Zapadnoj Rossii. (1887). Vil'na: izd. C. V. Šolkovič.

Teodorovič, N. I. (1893). Gorod Vladimir Volynskoj gubernii v svâzi s istoriej volynskoj eparhii, istoričeskij očerk. Počaev.

Čistovič, I. A. (1882). Očerk istorii zapadnorusskoj cerkvi (č. I.). Sankt-Peterburg. 